\title{
Adhesion Molecules and the Cellular Population of the Normal Camel (Camelus dromedaries) Mammary Glands
}

\author{
K.T. AL-Mohammed Salem ${ }^{1}$, S.Y. AL Ramadan² and A.M. Alluwaim ${ }^{*}$

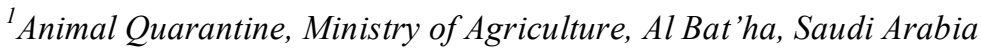 \\ ${ }^{2}$ Department of Anatomy, ${ }^{3}$ Department of Microbiology and Parasitology, College of Veterinary Medicine, King Faisal, \\ Al Ahsaa, Saudi Arabia
}

\begin{abstract}
The demand to camel's (Camelus dromedaries) milk is increasing worldwide. The new advances in the dairy industry have made the camel milk production on the commercial level is possible. The camel mammary glands immune system is not explored in detail. This study was conducted to identify the cell adhesion molecules involved in the regulation of the cells trafficking to the camel mammary glands at two different physiological stages; lactation and nonlactating periods. The expression and distribution of $\mathrm{CD}$ markers and the adhesion molecules, $\mathrm{CD} 4^{+}, \mathrm{CD} 8^{+}, \mathrm{MAdCAM}-1$, $\mathrm{WC}+1^{+}, \mathrm{CD} 62 \mathrm{~L}, \mathrm{CD} 11 \mathrm{a} / \mathrm{CD} 18$ (LFA-1), VCAM-1, TCR- $\alpha \beta, \mathrm{CD} 44^{+}$and CD20 $0^{+}$in the alveolar tissues, supramammary lymph nodes, Peyer's patches and mesenteric lymph node of the healthy camels were explored. The expression of the adhesion molecules was determined in situ by immunohistochemical technique using immunoperoxidase staining. MAdCAM-1 was detected in almost all the tissues at the two physiological stages in which high expression was evident in the non-lactating period. $\mathrm{CD} 8^{+} \mathrm{T}$-cells were detected in both mammary alveolar tissues and the supramammary lymph nodes, with the highest expression observed in the lactating period. $\mathrm{WC}+1^{+}$expression on $\gamma \delta$ cells were evident in mammary tissues and supramammary lymph nodes at both stages; however, the expression was higher in the non-lactating period. The detection of $\mathrm{CD} 20^{+}, \mathrm{CD} 62 \mathrm{~L}, \mathrm{VCAM}-1, \mathrm{TCR}-\alpha \beta$, and $\mathrm{CD} 44^{+}$expression failed despite their expression in the original species that the antibodies were raised against. The expression of CD4 ${ }^{+}$and CD11a/CD18 (LFA-1) were not detected at all.

The intensive expression of the MAdCAM-1 in the camel mammary glands could indicates that camel mammary glands cells trafficking is closely linked to the intestinal immune system (mucosal) rather than peripheral as it is well known for the bovine mammary glands. The high expression of $\mathrm{WC}+1^{+}$strongly reflects the importance of these cells subset in the defense mechanism of the camel mammary glands during the late lactation.
\end{abstract}

Keywords: Camel, adhesion molecules, $\mathrm{WC}+1^{+}, \mathrm{CD} 8^{+}$, MAdCAM-1, gamma delta cells, mammary glands.

\section{INTRODUCTION}

Dromedary camel (Camelus dromedarius) is one of the highly valuable domestic animals in Saudi Arabia. Camel is multipurpose animal that can be used for meat, milk, and wool production. In addition to the previous traditional commodities, modern applications in the dairy industry lead to the development of camel dairy farms that are capable of producing camel milk on the commercial level. Camel milk and meat are considered an important source of proteins for wide range of population [1]. It was estimated that world camel milk market worth 10 billion dollars [2].

Similar to cow, the camel mammary gland is consisted of four glandular quarters and it is located in the inguinal region. The left and right halves of the udder are separated from each other by fibroblastic tissue extending from the linea alba and pre pubic tendon. A groove is generally visible between the left and right halves, which is more distinct in the lactating than in the dry period. The lateral

*Address correspondence to this author at the Department of Microbiology and Parasitology, College of Veterinary Medicine, King Faisal, Al Ahsaa, Saudi Arabia; Tel: +966540924792; Fax: +966 3 5816345;

E-mail: alluwaimi@kfu.edu.sa aspect of the quarters is covered by tissue from the abdominal tunica and the caudal abdominal wall. Although the anterior (front) and posterior (back) quarters are independent and totally separated, the separation between them is invisible from the outside [3]. The camel mammary gland however, has no gland cistern i.e. no milk reservoir beyond the teat cistern but consisted of compound tubulealveolar glands, parenchyma, connective tissue stroma, ducts, and alveolar systems, similar to those of the cow [3]. Schwartz and Dioli, (1992) [4] demonstrated that the bovine teats possess only one duct cistern whereas, the teat of the camel possess 2-3 cisterns. Each teat cistern is spindle shape, tapers distally, and possess streak canal. The streak canals are short and small so that ordinary cannula used in the udder of the cow is too large for the camels [4].

Certain differences were observed between bovine and camel milk and colostrum constituents [5, 6]. Camel colostrum and milk is dominated by enzyme inhibitory subclasses $\operatorname{IgG} 2$ and $\operatorname{IgG} 3$, whereas $\operatorname{IgA}$ is present with lower concentration in colostrum [5,6]. Camel milk is also rich with several inhibitory proteins, like high concentration of lysozyme, lactophorin (proteose peptone component-3), which is a member of the glycosylation-dependent cell adhesion molecule-1 (GlyCAM-1), and the peptidoglycan 
recognition protein (PGRP) that plays important role in preventing the adhesion and bacterial multiplication [6].

The nature of the immune responses in the camel mammary gland is not fully explored. Studies on the cellular populations of the camel mammary glands and the lymphocytes trafficking in health and disease are very scarce.

Lymphocyte trafficking to the mammary glands is under the influence of adhesion molecules (AM). Expression of AM such as selectins, like CD62L, and integrins, like mucosal addressin cell-adhesion molecule-1 (MAdCAM-1) dictate the type of recruited cells and their homing destination [7]. Therefore, AM expression is vital in determining the mammary glands cellular populations in health and disease.

Studies on the bovine mammary glands revealed extensive variation in the scale and types of AM that are expressed at different of lactation period [8,9]. For instance, $\mathrm{CD}^{+}$T-lymphocytes prevail during the lactation period, whereas the $\mathrm{CD}^{+}: \mathrm{CD}^{+}$ratio increases toward the $\mathrm{CD} 4^{+}$at the end of the lactation period [10].

Lymphocytes recirculation is either of peripheral or mucosal nature [11]. Kehrli and Harp (2001) [11] have shown a difference in the lymphocyte recirculation from mucosal and peripheral tissue between the mammary glands of the ruminant and other monogastric animals. It appears that ruminant cell trafficking pathway is not part of the common mucosal immune system as it was defined for the monogastrics. In mice, MAdCAM-1 is expressed in Peyer's patches, gut lamina properia, and mesenteric lymph node, however in ruminant; MAdCAM-1 expression is missing in these tissues [12-15]. In accordance with this findings, it was therefore, clearly demonstrated that lymphocytes that home from MAdCAM-1 expressing tissues are of mucosal origin as in the monogastric animals, whereas, cells that home from tissues that lack MAdCAM-1 expression are of peripheral nature like in most of the ruminant animals [11]. The origin of the cells trafficking plays a major role in dictating route of vaccination and pathogenesis of different mastitis.

The aim of this study was to reveal types of expressed $\mathrm{AM}$ and the cellular population in the camel healthy mammary glands at different lactation periods. The role of the AM in normal mammary glands was seen essential in understanding the nature of the immune activities in camel mammary glands and resistance to mastitis at different physiological stages. This study also aimed to reveal the nature of the cells trafficking to camel mammary glands whether it is of peripheral or mucosal nature.

\section{MATERIAL AND METHODS}

\subsection{Animals and Tissue Collection}

Samples were collected from healthy 10 years-old multiparious female dromedary camels (Camelus dromedarius). Immediately after slaughter at (Alomran Slaughter House, Alahsa, Eastern Province, Saudi Arabia, the mammary glands were examined and only those free from any gross pathological changes during postmortem examination were selected.
Five lactating (mid-lactation) and other five non-lactating (dry period or late-lactation) mammary glands were excised. Immediately after slaughter, the tissue samples were collected from parenchyma, supramammary lymph node, Peyer's patches, and mesenteric lymph node. The samples were dissected out from any connective tissues before it was immersed in a fixative (4\% paraformaldehyde in PBS (PH 7.4).

\subsubsection{The Preparation of the Collected Samples}

The fixed samples were kept for 48 hours at room temperature for the routine histological and immunohistochemical techniques. After fixation, the specimens were trimmed to about $0.5 \mathrm{~cm}$ and dehydrated in ascending grades of alcohol $(70 \%=3$ hours, $70 \%=2.5$ hours, $80 \%=2$ hours, $80 \%$ $=1.5$ hours, $90 \%=1.5$ hours, $95 \%=1.5$ hours, $100 \%=1.5$ hours X2) cleared in xylene (1.5 hours X2) and subsequently embedded in paraffin wax as blocks (1.5 hours X2) using automated tissue processor (TP 1020, Leica, Germany). Then sectioned at $5 \mu \mathrm{m}$ thickness with rotary microtome (RM 2135 , Leica, Germany). The sections were floated in warm water bath $\left(41^{\circ} \mathrm{C}\right)$. Then sections were mounted on the super frost plus glass slides for conducting both routine histological and immunohistochemical techniques.

\subsection{Histology}

The slides were then cleared in xylene and rehydrate in descending grades of alcohol, washed in distilled water for staining. Heamatoxylin and eosin (H\&E) stain were performed for general histology to differentiate between various stages of lactation. Briefly, sections were deparaffinized and hydrated to distilled water. Sections then stained with Ehrlich Heamatoxylin for 5-10 minutes to stain the nuclei, washed in running tap water for 15-20 minutes, followed by Eosin stain for 5-10 minutes. After that, sections were dehydrated in ascending grade of alcohol, cleared with xylene and coversliped in DPX. These slides were then examined with light microscope at magnifications of $5 \times$, $10 \times, 40 \times$, and $100 \times$. Histological images were obtained with an Olympus BX 41 microscope and Olympus DP-12 digital camera (Olympus Corp., Tokyo, Japan).

\subsection{Monoclonal Antibodies}

The Primary and secondary antibodies that were used for the immunohistochemical staining are listed in Table 1. All primary and secondary antibodies are of murine origin. The secondary antibodies with 3-amino-9-ethylcarbazole (AEC) and visualized by horseradish peroxidase (HRP) (HRP-AEC) (anti-Mouse Kit, R\&D systems).

\subsection{Immunohistochemistry}

The tissue sections for immunohistochemical techniques of $5 \mu \mathrm{m}$ thickness were mounted on superfrost plus glass slides and were dewaxed in xylene and rehydrated in descending grades of alcohol, washed in phosphate buffered saline PBS (PH 7.4).

Then sections were processed according to the manufacturer's directions (R\&D systems Inc., HRP-AEC mouse kit system, Minneapolis, Minnesota, US). Briefly, sections were bordered by Dako pen and then washed in PBS. From this point on, all the incubations except for the primary antibodies were performed at room temperature in a humidity box. The 
Table 1. Primary Antibodies

\begin{tabular}{|c|c|c|c|c|}
\hline Markers & Clone & Isotype & Concentration & Source \\
\hline \hline Mouse anti-bovine CD8 & CC63 & IgG2a & $2 \mu \mathrm{g} / \mathrm{ml}$ & AbD Serotec \\
\hline Mouse anti-bovine WC+1 & CC15 & IgG2a & $2 \mu \mathrm{g} / \mathrm{ml}$ & AbD Serotec \\
\hline Mouse anti-human MAdCAM-1 & $17 \mathrm{FS}$ & IgG1 & $1 \mu \mathrm{g} / \mathrm{ml}$ & AbD Serotec \\
\hline Mouse anti- human CD62L & $9 \mathrm{H} 6$ & IgG2a & $2 \mu \mathrm{g} / \mathrm{ml}$ & Abcam \\
\hline Mouse anti- rat CD11a/CD18 (LFA-1) & OX42 & IgG2a & $1 \mu \mathrm{g} / \mathrm{ml}$ & Abcam \\
\hline Mouse anti-human VCAM-1 & BBIG-VA $(4 \mathrm{~B} 2)$ & IgG1 & $1 \mu \mathrm{g} / \mathrm{ml}$ & R\&D Systems, Inc \\
\hline Mouse anti-rat TCR $\alpha \beta$ & R73 & IgG1 & $0.5 \mu \mathrm{g} / \mathrm{ml}$ & BD Biosciences \\
\hline Mouse anti-human CD44 ${ }^{+}$ & $2 \mathrm{~F} 10$ & IgG1 & $0.5 \mu \mathrm{g} / \mathrm{ml}$ & R\&D Systems \\
\hline Mouse anti-bovine CD4 ${ }^{+}$ & CC30 & IgG1 & $10 \mu \mathrm{g} / \mathrm{ml}$ & AbD Serotec \\
\hline Mouse anti-human CD20 & $7 \mathrm{D} 1$ & IgG1 & $1 \mu \mathrm{g} / \mathrm{ml}$ & AbD Serotec \\
\hline
\end{tabular}

incubation with the primary antibodies however, was conducted over night at $4{ }^{\circ} \mathrm{C}$. First, sections were incubated with $3 \%$ hydrogen peroxide for $5 \mathrm{~min}$. to quench the endogenous peroxidase activity followed by $5 \mathrm{~min}$. wash in PBS. Sections were then incubated with normal blocking serum for $15 \mathrm{~min}$. Then, excess serum was drained off and then the sections were incubated with avidin blocking reagent (15 min.), briefly washed, followed by incubation with biotin blocking reagent (15 min.). After brief rinsing with buffer, the slides were incubated overnight at $4{ }^{\circ} \mathrm{C}$ with optimal concentration of primary antibody diluted in reagent buffer (Table 1). Sections were washed three times with PBS, drained carefully and were incubated with secondary biotinylated antibodies for $30-60$ min. After washing with PBS, the sections were incubated with streptavidin-HRP conjugate (HSS-HRP) for $30 \mathrm{~min}$. and finally washed. Visualization was achieved by immersing sections in freshly prepared AEC chromogen solution until desired stain intensity developed. The reaction was stopped by rinsing the sections with distilled water. Finally, slides were washed with distilled water for $5 \mathrm{~min}$. mounted by aqueous mounting medium for observation. These sections were evaluated using a light microscope at magnifications of $5 \times, 10 \times, 40 \times$, and $100 \times$. Histological images were obtained with an Olympus BX 41 microscope and Olympus DP-12 digital camera (Olympus Corp., Tokyo, Japan).

\subsection{Immunohistochemical Negative Control}

The staining was performed as before except that the primary antibodies were replaced with PBS, while the rest of procedures were maintained. Controls were carried out on sections adjacent to those used in normal immunostaining protocol.

Intensity of immunoreactive staining was scored by two independent observations using the following range: Negative; (-) Weak; (+) Moderate; $(++)$ Strong; (+++) Very strong $(++++)$.

\section{RESULTS}

\subsection{Haematoxylin and Eosin Staining (H \& E Staining)}

The H\&E staining of the collected samples revealed clearly the normal structure and the cellular distribution of parenchyma in the lactating and the non-lactating mammary glands, lymph nodes and Peyer's patches (Figs. 1-3).
The H\&E staining of the non-lactating mammary glands indicated abundant connective tissue stroma. The lobules are seen to consist of intralobular ducts lined by simple cuboidal epithelium resting on a basement membrane. The epithelial lining of the lactiferous duct indicated gradual transformation from pseudostraitfied columnar in the initial part to stratified cuboidal or columnar in the lactiferous sinus. Incomplete layer of myoepithelial cells between the ductal epithelium and the basal lamina.

The H\&E staining of the lactating mammary glands, however revealed that the lobules are packed with secretory alveoli, among which are seen some intralobular ducts. The intralobular and interlobular connective tissues are decreased in amount. Active alveoli are lined by low columnar epithelium and their lamina are filled with secretion, which appears as eosinophilic material containing vacuoles of dissolved fat. Resting alveoli have empty lumina and their cells are tall columnar.

\subsection{The Expression of the Adhesion Molecules and the CD Markers at the Lactating and Non-Lactating Tissues Using Immunostaining}

The labeling intensity of cells was scored on a subjective scale of: Negative; (-) Weak; (+) Moderate; (++) Strong; $(+++)$ Very strong $(++++)$.

\subsection{The Adhesion Molecules and the CD Markers of the Lactating Tissues}

Strong expression of $\mathrm{CD}^{+}$was revealed in the alveolar tissue, supramammary and mesenteric lymph nodes and Peyer's patches (Fig. 1). On the other hand, the $\mathrm{CD}^{+}$ expression in the mammary glands parenchyma was restricted to the alveoli (Fig. 1).

The MAdCAM-1 and the work shop cluster $+1^{+}\left(\mathrm{WC}+1^{+}\right)$ subtype $\gamma \delta$ T-cells of the lactating camels indicated moderate expression in all of the tissues (Figs. 2, 3).

The expression of the adhesion molecules and the CD markers, $\mathrm{CD} 4^{+}, \mathrm{TCR} \alpha \beta, \mathrm{CD} 20^{+}, \mathrm{CD}_{4} 4^{+}, \mathrm{CD} 62 \mathrm{~L}$, vascular cell adhesion protein-1 (VCAM-1) and integrin leukocyte function antigen-1 (LFA-1) were not detected at both lactating stages. However, their expression was detected in 


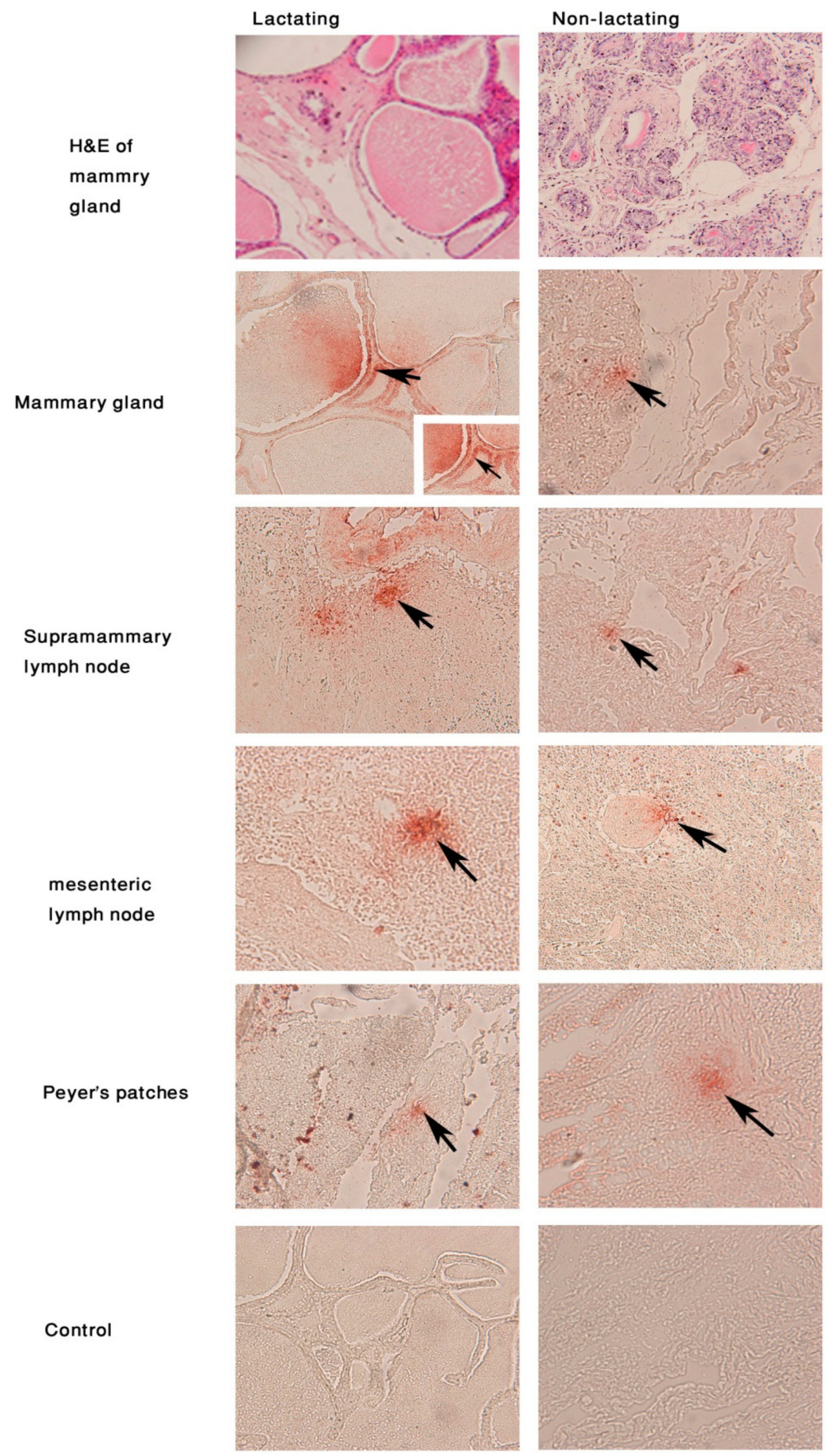

Fig. (1). The H\&E staining of the mammary gland at the two stages of the lactations period is indicated in the upper panels, whereas the lower panels depict the $\mathrm{CD}^{+}$expression at different tissues. The panel at the bottom is the control to the immunostained tissues. 
Mammary gland

\section{Lactating}
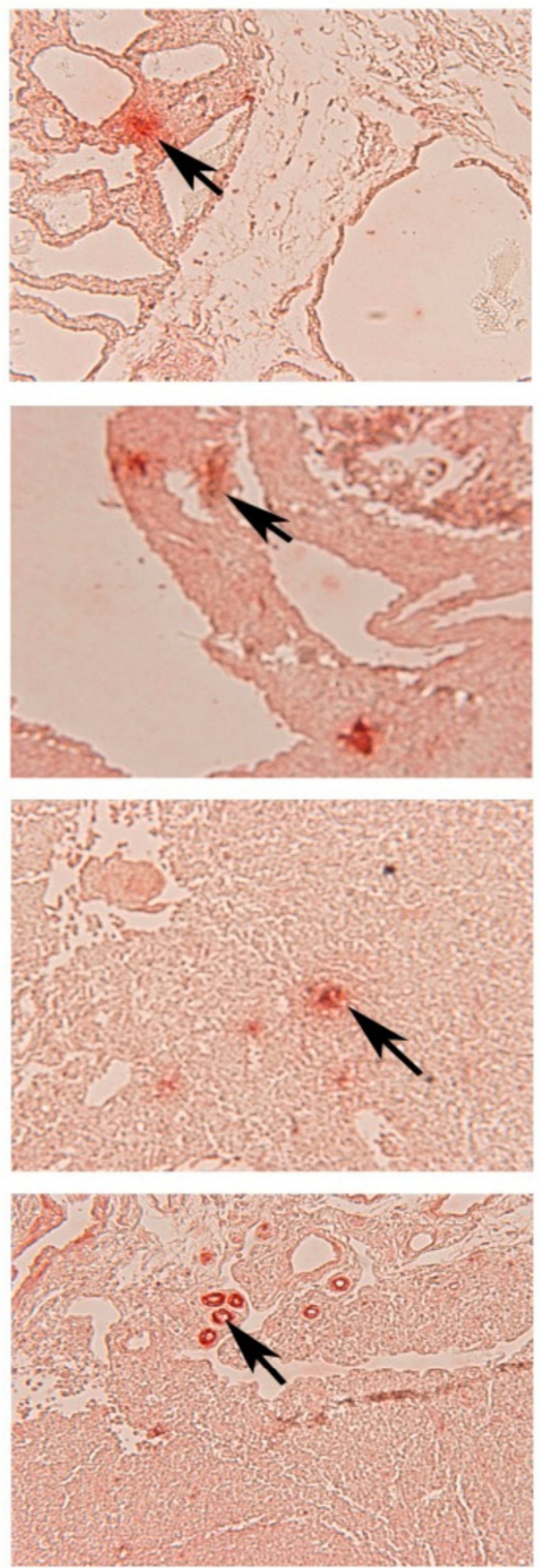

\section{Non-lactating}
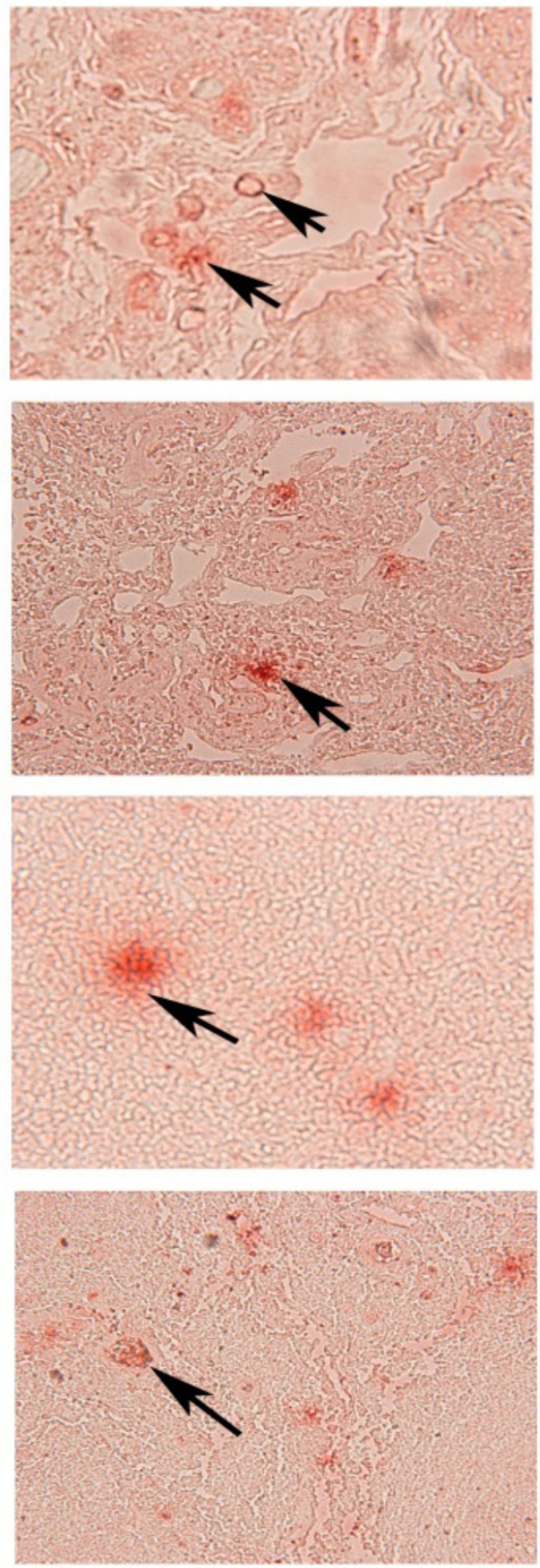

Fig. (2). The immunostaining with the anti-MAdCAM-1 antibodies indicated strong expression of this adhesion molecule in the nonlactating stage with prominent expression at the endothelium of the Peyer's patches and mesenteric lymph node.

the original species that the antibody rose against except LFA-1 and $\mathrm{CD}^{+}$were failed to be detected.

\subsection{The Adhesion Molecules and the CD Markers of the Non-Lactating Tissues}

The $\mathrm{CD}^{+}$marker was expressed moderately in the nonlactating tissues (Fig. 1). However, the MAdCAM-1 and $\mathrm{WC}+1^{+} \gamma \delta \mathrm{T}$ cells indicated very strong expression (Figs. 2, 3). MAdCAM-1 was strongly expressed in the alveolar tissue, supramammary and mesenteric lymph nodes and Peyer's patches (Fig. 2). The strong expression of MAdCAM- 1 and the $\mathrm{WC}+1^{+} \gamma \delta \mathrm{T}$ cells was diffused in the vascular endothelium of mesenteric and supramammary lymph nodes. However, the expression in the vascular endothelium of Peyer's patches was restricted to the submucosal region (Figs. 2, 3). The strong expression of $\mathrm{WC}+1^{+} \gamma \delta \mathrm{T}$ cells in the mammary glands was localized in the connective tissue (Fig. 3). 


\section{Lactating}

Mammary gland

\section{Supramammary lymph node}

\author{
Mesenteric \\ lymph node
}

\section{Peyer's patches}
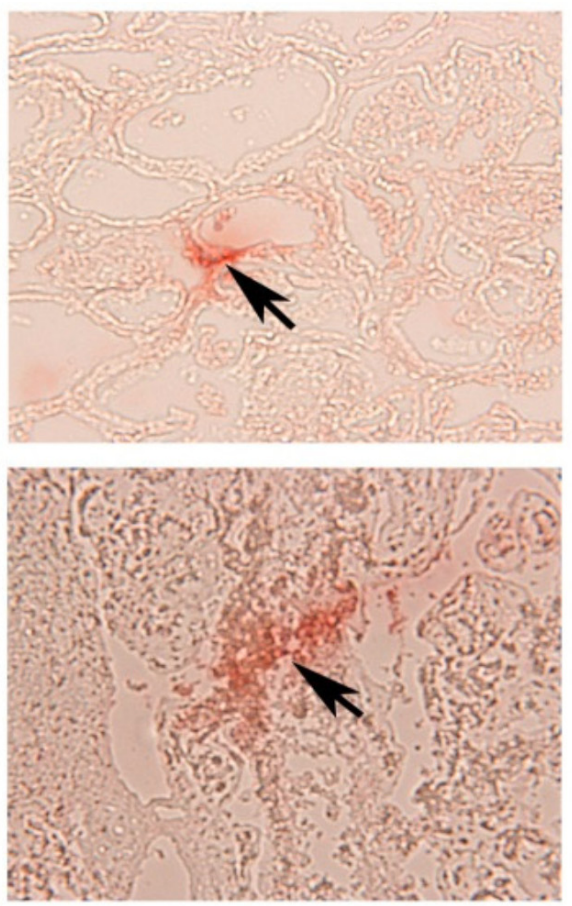

\section{Non-lactating}
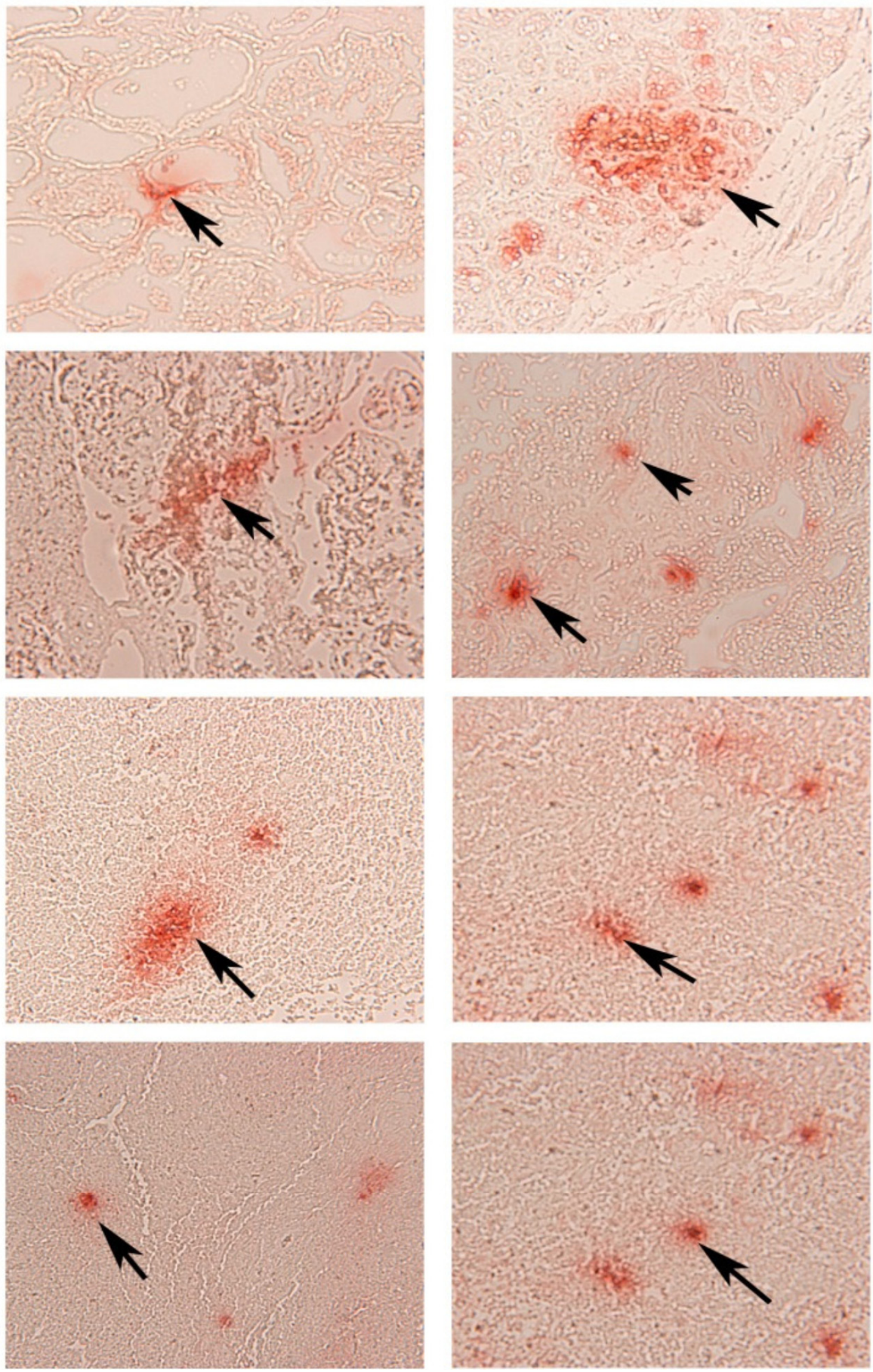

Fig. (3). The immunostaining with the anti-WC+1-antibodies indicated strong expression of this marker in the non-lactating stage with prominent expression in the alveolar tissue of the mammary gland.

\section{DISCUSSION}

Camel milk market was estimated 10 billion dollars annually [2]. Modern applications in the dairy industry lead to the development of camel dairy farms that are capable of producing camel milk on the commercial level. Commercializing camel milk production has created continuous pressure on the camel mammary glands to meet the increasing demand on its milk. Therefore, study of the camel mammary glands immune system becoming of high priority to understand the resistant mechanisms to mastitis.

Circulating leukocytes are the primary source of cells that transmigrate into the mammary glands of healthy and infected animals $[8,9]$. The migration of leukocytes from blood to the mammary glands depends on expression of AM. Adhesion molecules such as selectins, intergrins, and members of the immunoglobulin superfamily regulate signaling between the cells of the immune system and 
control the movement of leukocytes to the tissues and their interaction [7]. Hence, variations of the expressed AM indicate their role in the movement of different leukocytes into the mammary glands [10]. Overwhelming studies addressed the biological activities of the AM in the bovine mammary glands in health and disease $[9,13]$. Nevertheless, there are major lack of information about the nature of immune responses and the details of the camel mammary glands immune system. One of the important facets of the immune responses in the mammary glands is the expression of AM in health and disease. Hence, this study was carried out to reveal the pattern of the AM expression in the camel mammary glands at the lactating and non-lactating periods.

Due to the lack of camel specific primary antibodies, mouse anti-bovine, human and rat were used in accordance with previous studies [9, 11, 13-15]. Overall results indicated that these xenoantibodies were of good affinity in defining the target molecules like, $\mathrm{CD} 8^{+}, \mathrm{WC}+1^{+}$and MAdCAM-1. On the other hand, the antibodies that failed to react with the camel markers were CD62L, TCR $\alpha \beta$, VCAM-1, CD $44^{+}$, $\mathrm{CD} 20^{+}$but their reaction to the molecules of the original host could imply different possibilities. One of these is their lack of specificity to the camel AM or they might be weakly expressed in the non-inflamed tissues. Total failure in detecting the expression of $\mathrm{CD} 11 \mathrm{a} / \mathrm{CD} 18$ (LFA-1) and CD4 ${ }^{+}$ despite various efforts cannot be justified.

Results indicated strong and moderate expression of $\mathrm{CD} 8^{+}$at all studied tissues at the lactating and non-lactating mammary glands respectively. In the bovine mammary glands, $\mathrm{CD} 8^{+} \mathrm{T}$-lymphocytes prevail during the lactation period. However, $\mathrm{CD}^{+}: \mathrm{CD}^{+}$ratio tilt toward the $\mathrm{CD} 4+$ at the end of the lactation period [10]. Furthermore, Harp et al., (2004) [14] indicated over expression of the $\mathrm{CD} 8^{+} \mathrm{T}$ lymphocytes in milk in comparing to its level in the blood.

Workshop cluster $+1^{+}$was strongly expressed in the tissues of the non-lactating mammary gland. Majority of young bovine $\gamma \delta \mathrm{T}$-cells express $\mathrm{WC}+1+$ coreceptor. The $\mathrm{WC}+1^{+}$coreceptors that are expressed on the $\gamma \delta \mathrm{TCR}$ are identified with respect to their $\mathrm{CD} 8^{+}, \mathrm{CD}^{+}$, and $\mathrm{WC}+1^{+}$ expression and their cytokine profile [16-18]. $\mathrm{WC}+1^{+}$ coreceptor is transmembrane glycoprotein of the scavenger receptor cysteine rich (SRCR), a family that is usually expressed on the $\gamma \delta$ T cells $[19,20]$. The SRCR family of the $\mathrm{WC}+1^{+}$is composed of eleven domains with interdomains homology [22]. Study with wide range of monoclonal antibodies revealed that $\mathrm{WC}+1^{+}$corecptor is made of tow nonoverlaping variants, $\mathrm{WC}+1.1$ and $\mathrm{WC}+1.2$, whereas $\mathrm{WC}+1.3$ variant is coexpressed with the $\mathrm{WC}+1.1$ [20]. $\mathrm{WC}+1^{+}$coreceptors play major role in mediating the costimulatory signal in activation of $\gamma \delta \mathrm{T}$ cells [21]. Further studies on the role of the $\mathrm{WC}+1^{+}$have revealed a diverse genetic variation which could reach to at least $13 \mathrm{WC}+1^{+}$ genes on the bovine chromosome 5 [22]. $\mathrm{WC}+1^{+} \gamma \delta$ cells are found in blood, peripheral lymph nodes and skin. Nevertheless, there is no evidence of tissue tropism for the $\mathrm{WC}+1^{+}$expression in bovine tissue [20]

The proinflammatory activity of $\mathrm{WC}+1^{+} \gamma \delta \mathrm{T}$ cells was widely documented [18]. The copious production of interferon- $\gamma$ (IFN- $\gamma$ ) exerts a major influence in polarizing the immune responses toward the Th1 type responses (cell mediated responses) [23]. Rogers et al., (2005) [23] revealed that $\mathrm{WC}+1.1$ variant of $\gamma \delta \mathrm{T}$ cells are the source of high level of IFN- $\gamma$ production with the expression of high level of interleukin-12 receptor (IL-12R).

The $\gamma \delta$ cells coexpress different AM, like MAdCAM-1 and $\alpha 4 \beta 7$ integrins and selectively migrate to the lymphoid tissues that are enriched with chemokine receptors CCR7 [24]. Hence, the over expression of $\mathrm{WC}^{+} 1^{+}$in the nonlactating mammary tissues indicate the importance of this cells at this stage in which major immunological changes takes place [25]. However, the coexpression of the camel $\mathrm{WC}+1^{+} \gamma \delta$ T cells of the MAdCAM- 1 and $\alpha 4 \beta 7$ AM could refer to the mucosal nature of the cells trafficking system to mammary gland [11].

Similar to the $\mathrm{WC}+1^{+}$expression pattern, the MAdCAM1 was also strongly expressed in the tissues of the nonlactating mammary gland. It is possible that these molecules are those that are highly expressed on the $\mathrm{WC}+1^{+} \gamma \delta \mathrm{T}$ cells. MAdCAM-1 is a ligand of the Peyer's patches adhesion molecule-1 (LPAM-1), also known as $\alpha 4 \beta 7$. The therapeutic humanized anti- $\alpha 4 \beta 7$ monoclonal antibodies, Vedolizumab, was shown to inhibit the attachment of MAdCAM-1 to the $\alpha 4 \beta 7$ but not to the VCAM-1 [26]. In mice, MAdCAM- 1 is expressed in Peyer's patches, gut lamina properia and mesenteric lymph node [15]. Interestingly, the mucosal nature of the camel lymphocytes trafficking can be strongly advocated by the strong expression of MAdCAM-1 in the camel tissues, alveolar tissue, supramammary and mesenteric lymph nodes and Peyer's patches. However, in cattle, which their lymphocyte trafficking is of peripheral nature [11], MAdCAM-1 expression was seen missing in the above stated tissues [12].

In accordance with the above stated evidence, the over expression of MAdCAM-1 in the studied tissues of nonlactating camel mammary glands could strongly suggest that the lymphocytes trafficking to mammary glands in camel is of mucosal nature despite that it is a ruminant animal. However, absence of the secretory IgA in the camel milk could dispute this claim. Nevertheless, it was shown that the trafficking of the IgA secreting B lymphocytes to the murine mammary glands is $\alpha 4 \beta 7$ and MAdCAM- 1 independent [27]. It was demonstrated that blocking of VCAM-1 function has influenced the accumulation of the $\operatorname{IgA}$ secreting lymphocytes but not blocking of the MAdCAM-1 function [27]. However, further studies appear essential to endorse this claim beyond doubts.

In conclusion, the results indicated that the xenoantibodies rose against bovine, human and rat AM are efficient enough to detect the camel markers. The over expression of the MAdCAM- 1 and the $\mathrm{WC}+1^{+}$molecules at the late lactation strongly refer to essential role of these molecules in the up regulation of the immune responses at this period were mammary glands is highly susceptible to the mastitis. It was clearly demonstrated that mammary glands at late-lactation is approaching a stage of dramatic anatomical and physiological changes. These transient changes could subject the mammary glands to increasing susceptibility [25]. Hence, immunological changes at this stage could account for the enhancement in the efficiency of the mammary glands immune system. 


\section{ACKNOWLEDGEMENTS}

This work was supported by a grant from the Deanship of scientific research, King Faisal University and King Abdul Aziz City of Science and Technology (KACS).

\section{CONFLICT OF INTEREST}

The authors confirm that this article content has no conflict of interest.

\section{REFERENCES}

[1] Breulmann M, Böer B, Wernery U, et al. The Camel from tradition to modern times. Qatar: UNESCO Office, Doha 2007.

[2] Food and Agriculture Organization. Milking the camel. December 4, 2008. Available from: http://www.fao.org/AG/AGAINFO/themes/ en/dairy/camel. html

[3] Osman DI. Ismail HI. Morphology of the camel udder. Camel Forum. Working paper No 29. Somalia: Somali Acad Arts Sci 1988.

[4] Schwartz HJ, Dioli M. The One-humped Camel (Camelus dromedarius) in Eastern Africa: A pictorial guide to Diseases, Health Care and Management. Germany: Verlag Joseph Margraf Publishers 1992

[5] Azwai SM, Carter SD, Woldehiwet Z. Immunoglobulins of camel (Camelus dromedarius) colostrum. J Comp Pathol 1996; 114: 27382.

[6] El-Hatmi H, Girardet JM, Gaillard JL, et al. Characterisation of whey proteins of camel (Camelus dromedarius) milk and colostrum. Small Rumin Res 2007; 70: 267-71.

[7] Edelman GM, Crossin KL. Cell adhesion molecules: implications for a molecular histology. Annu Rev Biochem 1991; 60: 155-90.

[8] Simon M, Hluchý S, Horovská L, et al. Immunohistochemical localization of AMCD62 and CD18 in the mammary gland of dairy cows. Czech J Anim Sci 2007; 52: 88-95

[9] Van Kampen C, Mallard BA, Wilkie BN. Adhesion molecules, and lymphocyte subsets in milk and blood of periparturient Holstein cows. Vet Immunol Immunopathol 1999; 69: 23-32.

[10] Asai K, Kai K, Rikiishi, et al. Variation in $\mathrm{CD}^{+} \mathrm{T}$ lymphocyte subpopulations in bovine mammary gland secretions during lactating and non-lactating periods. Vet Immunol Immunopathol 1998; 65: 51-61.

[11] Kehrli ME, Harp JA. Immunity in the mammary gland. Vet Clin North Am Food Anim Pract 2001; 17: 495-516.

[12] Hodgkinson AJ, Carpenter EA, Smith CS, et al. Effects on adhesion molecule expression and lymphocytes in the bovine mammary gland following intra-mammary immunization. Vet Immunol Immunopathol 2009; 131:110-6.
[13] Hodgkinson AJ, Carpenter EA, Smith CS, et al. Adhesion molecule expression in the bovine mammary gland. Vet Immunol Immunopathol 2007; 115: 205-15.

[14] Harp JA, Waters, TE, Goff JP. Lymphocyte subsets and adhesion molecule expression in milk and blood of periparturient dairy cattle. Vet Immunol Immunopathol 2004; 102: 9-17.

[15] Van der Feltz MJ, De Groot N, Bayley JP, et al. Lymphocyte homing and Ig secretion in the murine mammary gland. Scand $\mathrm{J}$ Immunol 2001; 54: 292-300.

[16] Chiena Yh, Bonneville M. Gamma delta T cell receptors. Cell Mol Life Sci 2006; 63: 2089-94.

[17] Machugh ND, Mburu JK, Carolt MJ, et al. Identification of two distinct subsets of bovine cells with unique cell surface phenotype and tissue distribution. Immunology 1997; 92: 340-5.

[18] Wilson E, Hedges JF, Butcher EC, et al. Bovine $\gamma \delta$ T cell subsets express distinct patterns of chemokine responsiveness and adhesion molecules: a mechanism for tissue-specific cd $\mathrm{T}$ cell subset accumulation. J Immunology 2002; 169: 4970-5.

[19] Chen C, Carolyn TA, Herzig J, et al. Antigenic basis of diversity in the T cell co-receptor WC1 family. Mol Immunol 2009; 46: 25655.

[20] Rogers AN, VanBuren DG, Hedblom E, et al. $\gamma \delta \mathrm{T}$ Cell Function Varies with the Expressed WC1 Coreceptor. J Immunol 2005; 174: 3386-93.

[21] Wang F, Herzig CD, Baldwin CL, et al. Tyrosine phosphorylation of scavenger receptor cysteine-rich $\mathrm{WC1}$ is required for the WC1mediated potentiation of TCR-induced T-cell proliferation. Eur J Immunol 2009; 39: 254-66.

[22] Rogers AN, Vanburen DG, Zou B, et al. Characterization of WC1 co-receptors on functionally distinct subpopulations of ruminant gamma delta T cells. Cell Immunol 2006; 239: 151-61.

[23] Rogers AN, VanBuren DG, Hedblom E, et al. Function of ruminant $\gamma \delta \mathrm{T}$ cells is defined by WC1.1 or WC1.2 isoform expression. Vet Immunol Immunopathol 2005; 108: 211-7.

[24] Wilson E, Aydintug MK, Jutila MA. A circulating bovine $\gamma \delta \mathrm{t}$ cell subset, which is found in large numbers in the spleen, accumulates inefficiently in an artificial site of inflammation: correlation with lack of expression of E-selectin ligands and L-selectin. J Immunol 1999; 162: 4914-9.

[25] Alluwaimi AM, Cullor JS. Cytokines gene expression patterns of bovine milk during mid and late stage of lactation. J Vet Med B Infect Dis Vet Public Health 2002; 49: 105-10.

[26] Soler D, Chapman T, Yang L, et al. The binding specificity and selective antagonism of vedolizumab, an anti-4_7 integrin therapeutic antibody in development for inflammatory bowel diseases. J Pharmacol Exp Ther 2009; 330: 864-75.

[27] Lowa EN, Zagieboyloaa L, Martinoaa B, et al. IgA ASC Accumulation to the Lactating Mammary Gland is Dependent on VCAM-1 and alpha4 Integrins. Mol Immunol 2010; 47:1608-12.

(C) AL-Mohammed Salem et al.; Licensee Bentham Open.

This is an open access article licensed under the terms of the Creative Commons Attribution Non-Commercial License (http: //creativecommons.org/licenses/by$\mathrm{nc} / 3.0 /$ ) which permits unrestricted, non-commercial use, distribution and reproduction in any medium, provided the work is properly cited. 